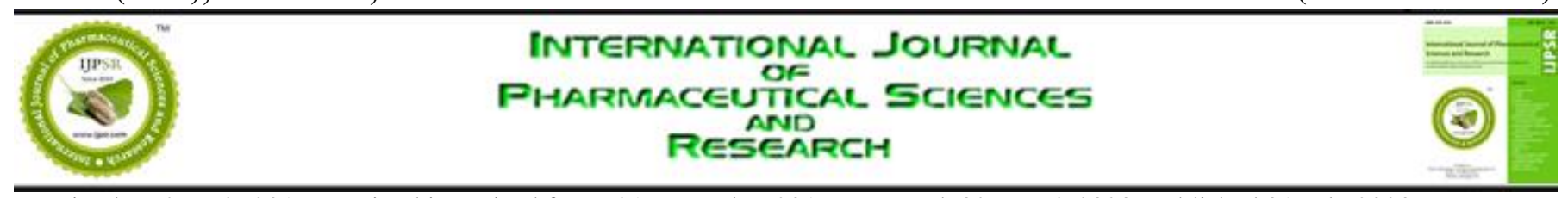

Received on 29 July 2019; received in revised form, 21 December 2019; accepted, 02 March 2020; published 01 July 2020

\title{
DEVELOPMENT AND VALIDATION OF STABILITY INDICATING HPTLC METHOD FOR ESTIMATION OF DARUNAVIR
}

\author{
Anuruddha R. Chabukswar ${ }^{1}$ and Ayushi S. Gadekar ${ }^{*} 2$
}

Department of Pharmaceutical Chemistry ${ }^{1}$, Dr. Vishwanath Karad MIT World Peace University, School of Pharmacy, Kothrud, Pune - 411038, Maharashtra, India.

Department of Pharmaceutical Chemistry ${ }^{2}$, MAEERS Maharashtra Institute of Pharmacy, Kothrud, Pune 411038, Maharashtra, India.

Keywords:

High-performance thin-layer chromatography (HPTLC), Darunavir, method validation, ICH guidelines, stability-indicating method

Correspondence to Author:

Mrs. Ayushi S. Gadekar

Department of Pharmaceutical Chemistry, MAEERS Maharashtra Institute of Pharmacy, Kothrud, Pune - 411038, Maharashtra, India.

E-mail: agadekar@gmail.com

\begin{abstract}
A simple, precise, and sensitive stability-indicating highperformance thin layer chromatographic (HPTLC) method has been developed and validated for the analysis of Darunavir in bulk and in the tablet dosage form. The separation was performed on pre-coated silica gel $60 \mathrm{GF}_{254}$ plates using Toluene: Methanol: Triethylamine $(8.5: 1: 0.5 \mathrm{v} / \mathrm{v} / \mathrm{v})$ as the mobile phase. The retention factor $\left(R_{f}\right)$ was found to be $0.61 \pm 0.89$. The detection of a band was carried out at $267 \mathrm{~nm}$. The drug was subjected to different stress conditions like acid, base hydrolysis, oxidation, thermal degradation, and photolysis. The method was successfully validated according to $\mathrm{ICH}_{2}(\mathrm{R} 1)$ guidelines. The linear regression analysis data for the calibration plot showed a good linear relationship with $\mathrm{R}^{2}=0.992$ in the range of 500-3000 $\mathrm{ng}$ band ${ }^{-1}$. The method found to be accurate as results of the recovery studies are close to $100 \%$. The developed method can be adopted for routine analysis of Darunavir in bulk and pharmaceutical dosage form.
\end{abstract}

INTRODUCTION: Darunavir is chemically [(3aS,4R,6aR)- 2,3,3a,4,5,6a-hexahydrofuro[2,3-b] furan-4-yl] N- [(2S,3R)-4- [(4-aminophenyl) sulfonyl-(2-methylpropyl)amino]- 3- hydroxy- 1- phenyl butan-2-yl] carbamate it is HIV protease inhibitor that is used in the treatment of AIDS and HIV infections. Darunavir is an antiretroviral protease inhibitor that is used in the therapy and prevention of human immunodeficiency virus (HIV) infection and the acquired immunodeficiency syndrome (AIDS). Darunavir can cause transient and usually asymptomatic elevations in serum aminotransferase levels and has been linked to rare instances of clinically apparent, acute liver injury.

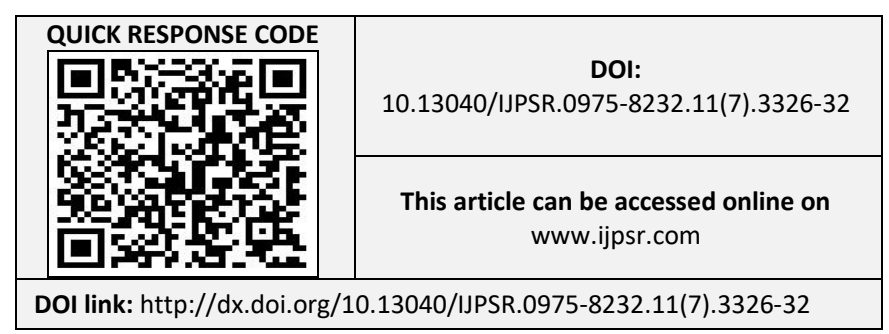

In $\mathrm{HBV}$ or $\mathrm{HCV}$ co-infected patients, highly active antiretroviral therapy with darunavir may result of an exacerbation of the underlying chronic hepatitis B or C. Literature survey reveals that few analytical methods have been reported for the estimation of Darunavir including UV-Vis spectroscopy 1,2 , high-performance liquid chromatography (HPLC) ${ }^{3,}$ 4, high-performance thin-layer chromatography (HPTLC) 5, 6, Infrared Spectroscopy (IR) 7 , Capillary Electrophoresis ${ }^{8}$, LC-MS/MS ${ }^{9,10}$.

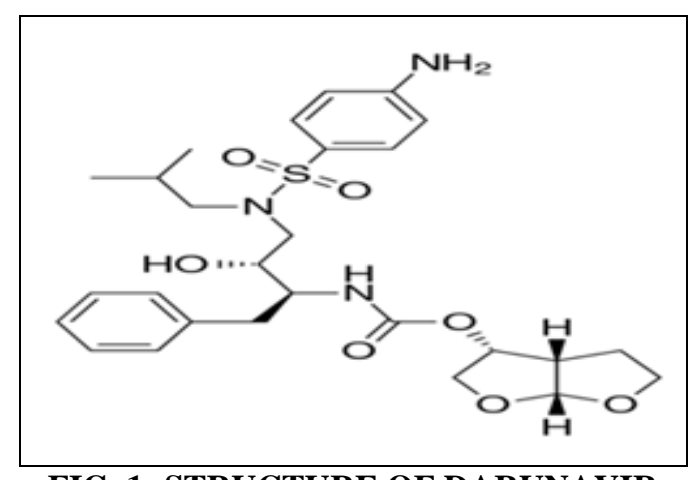

FIG. 1: STRUCTURE OF DARUNAVIR 


\section{MATERIALS AND METHODS:}

Reagents and Chemicals: 20 tablets each containing $300 \mathrm{mg}$ of Darunavir (Darunavir, Cipla Ltd.) was procured from the local market. Methanol (AR grade), Triethylamine (AR grade), toluene (AR grade) were purchased from S.D. Fine Chemical Laboratories, Mumbai. Hydrochloric acid $(\mathrm{HCl})$, acetic acid $\left(\mathrm{CH}_{3} \mathrm{COOH}\right)$, hydrogen peroxide $\left(\mathrm{H}_{2} \mathrm{O}_{2}\right)$, and sodium hydroxide $(\mathrm{NaOH})$; all $\mathrm{AR}$ grade were purchased from Loba Chemie Pvt. Ltd., Mumbai.

Chromatographic Conditions: Chromatographic separation of the drug was performed on aluminum plates precoated with silica gel $60 \mathrm{~F}_{254}(10 \mathrm{~cm} \times 10$ cm with $250 \mu \mathrm{m}$ layer thickness). The sample was applied on the plate as a band of $5 \mathrm{~mm}$ width using Camag $100 \mu \mathrm{l}$ sample syringe (Hamilton, Switzerland) with a linomat 5 applicator (Camag, Switzerland). The mobile phase was composed of Toluene: Methanol: Triehylamine (8.5:1:0.5 v/v/v). $10 \mathrm{~cm} \times 10 \mathrm{~cm}$ Camagtwin trough glass chamber was used for linear ascending development of TLC plate under $15 \mathrm{~min}$ saturation conditions and $10 \mathrm{ml}$ of mobile phase was used per run.

Migration distance was $80 \mathrm{~mm}$. Densitometric scanning was carried out using Camag TLC scanner at $267 \mathrm{~nm}$, operated by win CATS software (version 1.4.3), slit dimensions were $4.00 \times 0.45$ $\mathrm{mm}$ and Deuterium lamp was used as a radiation source.

Preparation of Standard Stock Solution: The standard stock solution of Darunavir was prepared by dissolving $10 \mathrm{mg}$ of drug in $10 \mathrm{ml}$ of methanol to get a concentration of $1000 \mu \mathrm{g} / \mathrm{ml}$. From the standard stock solution, the working standard solution was prepared to contain $100 \mu \mathrm{g} / \mathrm{ml}$ of Darunavir.

Selection of Analytical Wavelength: From the standard stock solution further dilutions were made using methanol and scanned over the range of 200 $-800 \mathrm{~nm}$ and the spectra were obtained. It was observed that the drug showed considerable absorbance at $267 \mathrm{~nm}$ Fig. 2.

Selection of Mobile Phase and Chromatographic Conditions: Chromatographic separation studies were carried out on the working standard solution of Darunavir $100 \mu \mathrm{g} / \mathrm{ml}$. Initially, trials were carried out using various solvents in various proportions on normal TLC plates to obtain the desired $R_{f}$ and shape for drug peak. After a few trials, Toluene: Methanol: Triethylamine (8.5:1:0.5 $\mathrm{v} / \mathrm{v} / \mathrm{v}$ ) was chosen as the mobile phase, which gave acceptable peak parameters.

Preparation of Sample Solution: 20 tablets each containing $300 \mathrm{mg}$ of Darunavir (Darunavir, Cipla Ltd.) was weighed and powdered. Powder equivalent to $10 \mathrm{mg}$ of drug was transferred to 10 $\mathrm{ml}$ volumetric flask and volume was made up with acetonitrile to get concentration $(1000 \mu \mathrm{g} / \mathrm{ml})$ and was sonicated for $10 \mathrm{~min}$. Solution was filtered, from this solution $1 \mathrm{ml}$ of drug was taken in $10 \mathrm{ml}$ volumetric flask and volume was made up with acetonitrile. Further dilution in acetonitrile was done to get concentration $10 \mu \mathrm{g} / \mathrm{ml}$.

\section{Densitogram and System Suitability Parameter} of Drug: Solution of Darunavir $(100 \mu \mathrm{g} / \mathrm{ml})$ was prepared. $10 \mu \mathrm{l}(1000 \mathrm{ng} / \mathrm{band})$ of solution was applied on pre-activated TLC plate with the help of Hamilton syringe $(100 \mu \mathrm{l})$, using Linomat 5 sample applicator. The development chamber was saturated with the mobile phase for $15 \mathrm{~min}$. The spotted plate was placed in the saturated chamber and developed up to $80 \mathrm{~mm}$ distance. The plate was dried and was scanned over $90 \mathrm{~mm}$ distance at 267 $\mathrm{nm}$. The retention factor was found to be: $0.61 \pm$ 0.89 Fig. 3, Table 1.

Stress Degradation Studies of Bulk Drug: Stress degradation studies were carried under the condition of acid as well base hydrolysis, oxidation, and dry heat. Dry heat and photolytic degradation were carried out in solid-state.

Preparation of Standard Stock Solution: Accurately weighed $25 \mathrm{mg}$ of Darunavir was transferred to the $5 \mathrm{ml}$ pre-calibrated volumetric flask. Darunavir was dissolved in small quantity of water. Volume was made up to $5 \mathrm{ml}$ with water to achieve a stock solution of $5000 \mu \mathrm{g} / \mathrm{ml}$ (Stock-1).

\section{Preparation of Sample:}

Degradation under Acid-Catalyzed Hydrolytic Condition: To $1 \mathrm{ml}$ of $5000 \mu \mathrm{g} / \mathrm{ml}$ solution of Darunavir, $1 \mathrm{ml}$ of $0.5 \mathrm{~N} \mathrm{HCl}$ was added. The above solution was kept for $4 \mathrm{~h}$ at room temperature. After exposure the solution was neutralized with $0.5 \mathrm{~N} \mathrm{NaOH}$ and volume was 
made up to $10 \mathrm{ml}$ with methanol $0.5 \mu \mathrm{l}$ of the resultant solution was then applied at TLC plate and densitogram was developed. 19.77\% Darunavir was recovered with no peak of degradant Fig. 4.

Degradation under Alkali Catalyzed Hydrolytic Condition: To $1 \mathrm{ml}$ of $5000 \mu \mathrm{g} / \mathrm{ml}$ solution of Darunavir, $1 \mathrm{ml}$ of $0.5 \mathrm{~N} \mathrm{NaOH}$ was added. The above solution was kept for $4 \mathrm{~h}$ at room temperature. After exposure, the solution was neutralized with $0.5 \mathrm{~N} \mathrm{HCl}$ and the volume was made up to $10 \mathrm{ml}$ with methanol. $5 \mu \mathrm{l}$ of the resultant solution was then applied at the TLC plate and densitogram was developed. Average 16.08\% of Darunavir was recovered with no peak of degradation Fig. 5.

Degradation under Oxidative Condition: To 1 $\mathrm{ml}$ of $5000 \mu \mathrm{g} / \mathrm{ml}$ solution of Darunavir, $1 \mathrm{ml}$ of 10 $\% \mathrm{H}_{2} \mathrm{O}_{2}$ was added. The above solution was kept for $1 \mathrm{~h}$ at room temperature. The volume was made up to $10 \mathrm{ml}$ with methanol. $5 \mu \mathrm{l}$ of the resultant solution was then applied at the TLC plate and densitogram was developed. Average $25.44 \%$ of Darunavir was recovered with no peak of degradant Fig. 6.

Degradation under Dry Heat: Dry heat studies were performed by keeping drug sample in the oven $\left(80^{\circ} \mathrm{C}\right)$ for a period of $4 \mathrm{~h}$. The sample was withdrawn, dissolved in methanol and diluted to get $500 \mu \mathrm{g} / \mathrm{ml}$. $5 \mu \mathrm{l}$ of the resultant solution was then applied at TLC plate and densitogram was developed. Average $76.33 \%$ Darunavir was recovered with no peak of degradant Fig. 7.

Photo-Degradation Studies: The photo degradation stability study of the drug was studied by exposing the drug to UV light providing illumination of NLT 200 watt $\mathrm{hr} / \mathrm{m}^{2}$. After exposure accurately weighed $10 \mathrm{mg}$ of drug was transferred to $10 \mathrm{ml}$ of the volumetric flask; the volume was made up with methanol to obtain 1000 $\mu \mathrm{g} / \mathrm{ml}$ solution. $5 \mathrm{ml}$ of the resultant solution was then diluted with methanol to get a concentration of $500 \mu \mathrm{g} / \mathrm{ml}$. $5 \mu \mathrm{l}$ of the resultant solution was then applied at the TLC plate, and densitogram was developed. Average $50.38 \%$ of Darunavir was recovered with no peak of degradant Fig. 8.

Validation of Analytical Method: ${ }^{11}$ The method was validated as per ICH Q2 (R1) guidelines.
Specificity: The specificity of the method was ascertained by peak purity profiling studies. The peak purity values were found to be more than 0.998, indicating the non-interference of any other peak of degradation product or impurity.

Linearity: From the standard stock solution $(1000 \mu \mathrm{g} / \mathrm{ml})$ of Darunavir, a solution was prepared to contain $100 \mu \mathrm{g} / \mathrm{ml}$. This solution was further used for spotting. Six replicates per concentration were spotted. The linearity (relationship between peak area and concentration) was determined by analyzing six concentrations over the concentration range of 500-3000 ng/band.

The results obtained are shown in Table 2, the peak areas were plotted against the corresponding concentrations to obtain the calibration curve as shown in Fig. 9.

Range: Darunavir $=500-3000 \mathrm{ng} / \mathrm{band}$

Precision: The precision of the method was demonstrated by intra-day and inter-day variation studies. In the Intra-day studies, 3 replicates of 3 concentrations were analyzed on the same day, and percentage RSD was calculated. For the inter-day variation studies, 3 replicates of 3 concentrations were analyzed on 3 consecutive days and percentage RSD was calculated. For intraday precision and inter-day precision results obtained are shown in Tables 3 and 4.

\section{Limit of Detection (LOD) and Limit of Quantification (LOQ):}

LOD and LOQ are calculated from the formula: -

$$
\begin{aligned}
& \mathrm{LOD}=3.3 \sigma / \mathrm{S} \\
& \mathrm{LOQ}=10 \sigma / \mathrm{S}
\end{aligned}
$$

Where, $\sigma=$ standard deviation of $Y$ intercept, $S=$ slope of the calibration curve Table 5.

Assay: Darunavir tablet formulation analysis was carried out as mentioned under section preparation of sample solution. Procedure was repeated for six times. $2 \mu$ volume of sample solution was applied and area was recorded.

Concentration and \% recovery was determined from linear equation. The results obtained are shown in Table 6. 
Accuracy: To check the accuracy of the method, recovery studies were carried by spiking the standard drug to the blend, at three different levels 50,100 and $150 \%$. The basic concentration of the sample chosen was $1000 \mathrm{ng} / \mathrm{band}$.

$\%$ recovery was determined from the linearity equation. The results obtained are shown in Table 7.

Robustness: Robustness of the method was determined by carrying out the analysis under conditions during which detection wavelength, chamber saturation time were altered, time was also changed from spotting to development and development to scanning and the effects on the area were noted.

It was found that the method is robust. The results obtained are shown in Table 8.

Summary of Validation Study: The summary of validation parameters are summarized in Table 9.

\section{RESULTS AND DISCUSSION:}

Selection of Analytical Wavelength: Detection wavelength was found to be $267 \mathrm{~nm}$.

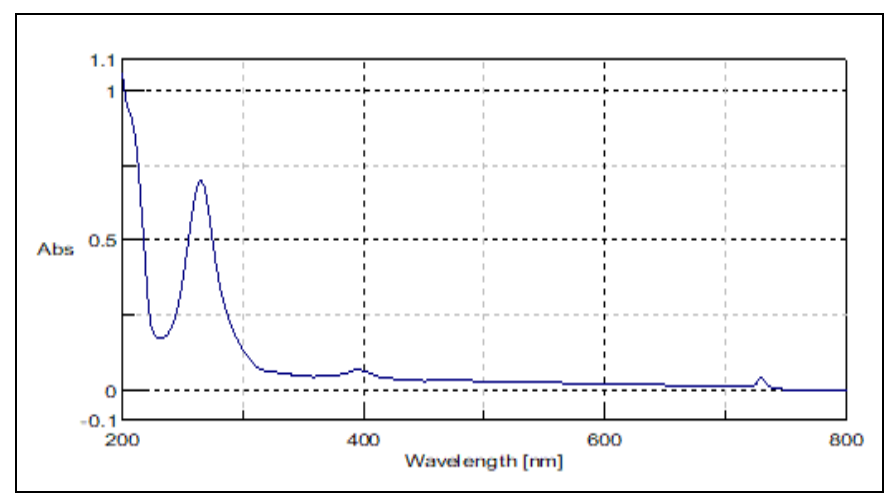

FIG. 2: UV SPECTRUM OF DARUNAVIR $(10 \mu \mathrm{g} / \mathrm{ml})$

\section{Typical Densitogram of Darunavir:}

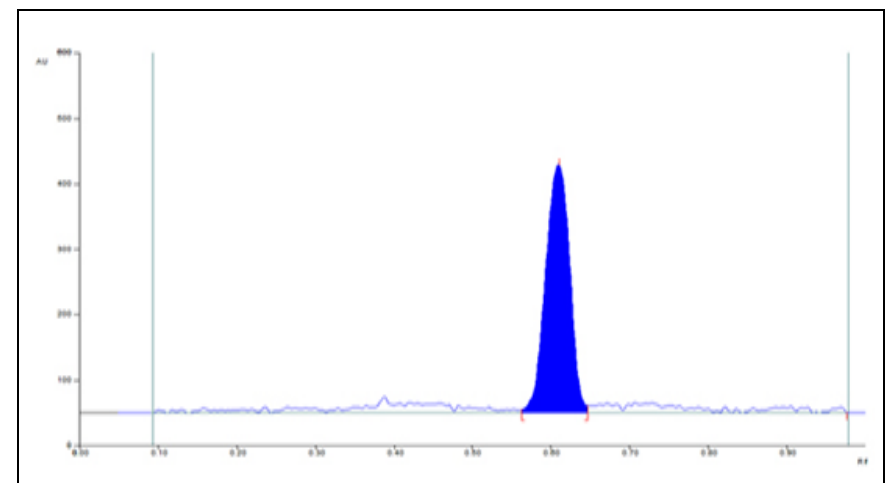

FIG. 3: A TYPICAL DENSITOGRAM OF STANDARD SOLUTION OF DARUNAVIR (1000 ng/band)
TABLE 1: SYSTEM SUITABILITY PARAMETERS FOR DARUNAVIR

\begin{tabular}{ccccc}
\hline Drug & $\begin{array}{c}\text { Conc. } \\
(\text { ng/band) }\end{array}$ & Rf & Area & Asymmetry \\
\hline Darunavir & 1000 & $0.61 \pm 0.89$ & 4267.6 & 1.13 \\
\hline
\end{tabular}

Stress Degradation Studies of Bulk Drug: Degradation under Acid-Catalyzed Hydrolytic Condition:

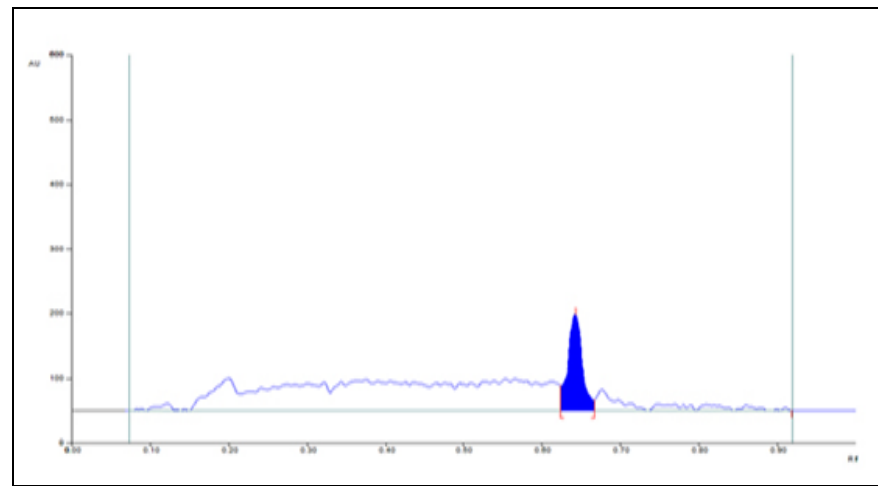

FIG. 4: REPRESENTATIVE DENSITOGRAM OF ACID INDUCED DEGRADATION OF DARUNAVIR (2500 ng/band)

Degradation under Alkali Catalyzed Hydrolytic Condition:



FIG. 5: REPRESENTATIVE DENSITOGRAM OF BASED INDUCED DEGRADATION OF DARUNAVIR (2500 ng/band)

\section{Degradation under Oxidative Condition:}

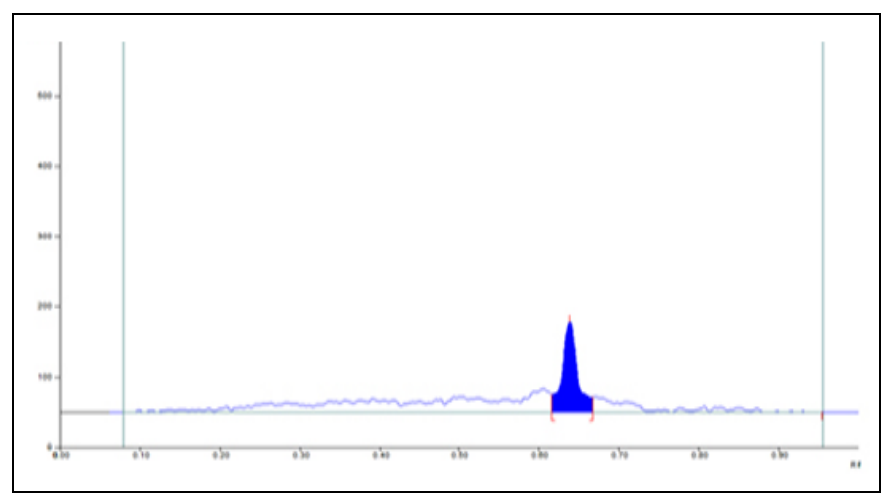

FIG. 6: REPRESENTATIVE DENSITOGRAM OF OXIDATIVE DEGRADATION OF DARUNAVIR (2500 ng/band) 


\section{Degradation under Dry Heat:}

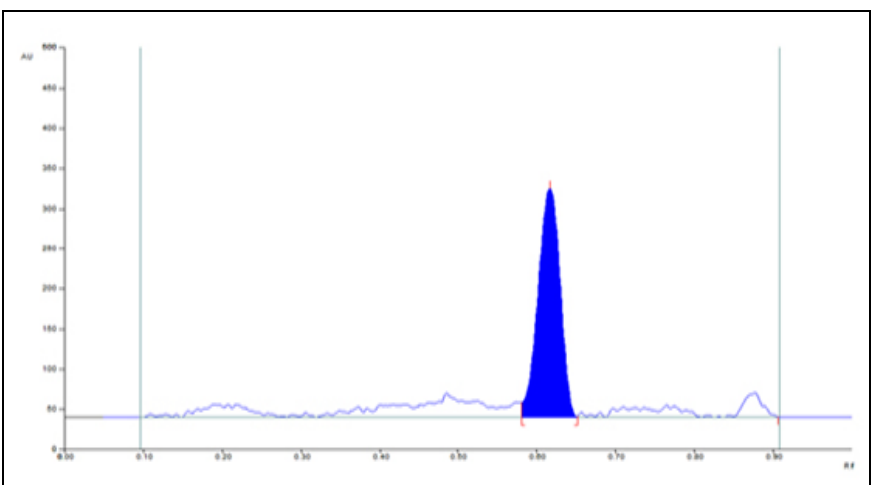

FIG. 7: REPRESENTATIVE DENSITOGRAM OF DRY HEAT DEGRADATION OF DARUNAVIR (2500ng/band)

\section{Photo-Degradation Studies:}

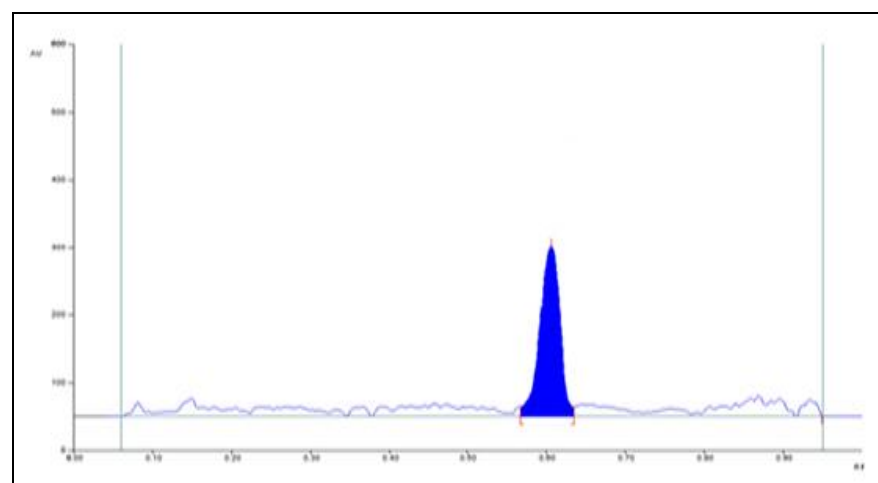

FIG. 8: REPRESENTATIVE DENSITOGRAM OF DARUNAVIR AFTER PHOTOLYSIS (2500 ng/band)

Validation of Analytical Method: Linearity:

TABLE 2: LINEARITY STUDY OF DARUNAVIR

\begin{tabular}{|c|c|c|c|c|c|c|}
\hline \multirow[t]{2}{*}{ Replicate } & \multicolumn{6}{|c|}{ Concentrations of Darunavir (ng/band) } \\
\hline & 500 & 1000 & 1500 & 2000 & 2500 & 3000 \\
\hline 1 & 1866.7 & 4267.6 & 6334 & 8025.5 & 9866.2 & 11066.3 \\
\hline 3 & 1866.7 & 4305.3 & 6452.8 & 8035.7 & 9745.9 & 11543.2 \\
\hline 4 & 1824.7 & 4267.6 & 6500 & 8035.4 & 9710 & 11587.3 \\
\hline 5 & 1851.4 & 4267.3 & 6455.3 & 8025.9 & 9763.2 & 11563.7 \\
\hline SD & 26.47 & 34.82 & 57.12 & 31.62 & 65.37 & 96.45 \\
\hline$\%$ RSD & 1.43 & 0.81 & 0.88 & 0.40 & 0.66 & 0.84 \\
\hline
\end{tabular}

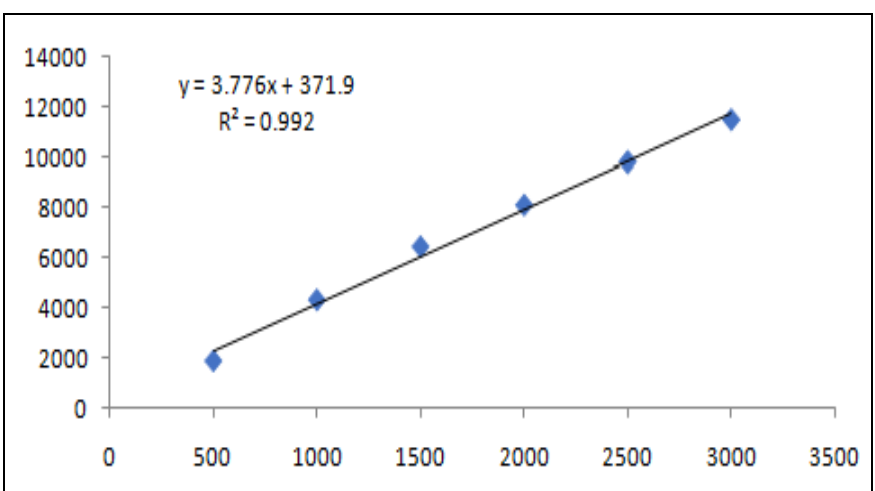

FIG. 9: CALIBRATION CURVE FOR DARUNAVIR

Range: Darunavir $=500-3000 \mathrm{ng} / \mathrm{band}$

\section{Precision:}

TABLE 3: INTRA-DAY PRECISION OF DARUNAVIR

\begin{tabular}{ccccc}
\hline Conc. (ng/band) & Area & Mean area & SD & \% RSD \\
\hline 1000 & 4587.9 & 4572 & 14.41 & 0.49 \\
& 4559.8 & & & \\
\multirow{2}{*}{1500} & 4568.3 & 6017.3 & 15.63 & 0.39 \\
& 6005.3 & & & \\
\multirow{2}{*}{2000} & 6012.3 & 7480.93 & 21.25 & 0.36 \\
& 6035.2 & & & \\
\hline
\end{tabular}


TABLE 4: INTER-DAY PRECISION OF DARUNAVIR

\begin{tabular}{ccccc}
\hline Conc. $(\mathbf{n g} /$ band) & Area & Mean area & SD & \% RSD \\
\hline 1000 & 4556.3 & 4570.6 & 0.53 & 0.54 \\
& 4568.3 & & & \\
1500 & 4587.3 & 6089.3 & 0.18 & 0.17 \\
& 6035.5 & & & 0.06 \\
2000 & 6210.3 & 7490.03 & 0.06 & \\
& 7485.1 & & \\
\hline
\end{tabular}

Limit of Detection (LOD) and Limit of Quantification (LOQ):

TABLE 5: LOD AND LOQ OF DARUNAVIR

\begin{tabular}{ccccc}
\hline Method & Avg. slope & S.D & LOD (ng/band) & LOQ (ng/band) \\
\hline S.D of y-intercept & 3.756 & 108.28 & 95.12 & 288.24 \\
\hline
\end{tabular}

Assay:

TABLE 6: ASSAY OF MARKETED FORMULATION

\begin{tabular}{cccc}
\hline S. no. & Peak area & Amount Recovered (ng/band) & \% Recovery \\
\hline 1 & 4122.3 & 993.16 & 99.31 \\
2 & 4123.9 & 993.59 & 99.35 \\
3 & 4142.6 & 998.54 & 99.85 \\
4 & 4152.3 & 1001.11 & 100.11 \\
5 & 4147.3 & 999.78 & 99.97 \\
6 & 4176.3 & 1007.46 & 100.74 \\
Mean & 4144.11 & 998.94 & 99.89 \\
\%RS & 0.48 & 0.53 & 0.55 \\
\hline
\end{tabular}

Accuracy:

TABLE 7: RECOVERY STUDIES OF DARUNAVIR

\begin{tabular}{ccccccc}
\hline Level (\%) & $\begin{array}{c}\text { Sample } \\
\text { (ng/band) }\end{array}$ & $\begin{array}{c}\text { Std. } \\
\text { (ng/band) }\end{array}$ & Area & $\begin{array}{c}\text { Recovered } \\
\text { Conc. (ng/band) }\end{array}$ & $\begin{array}{c}\text { \% } \\
\text { Recovery }\end{array}$ & $\begin{array}{c} \pm \\
\text { RSD }\end{array}$ \\
\hline 50 & 1000 & 500 & 6058.3 & 1505.85 & 100.39 & 0.26 \\
& & & 6065.9 & 1507.85 & 100.52 & \\
100 & \multirow{2}{*}{1000} & 1000 & 6087.3 & 1513.53 & 100.90 & \\
& & & 7875.6 & 1987.10 & 99.35 & 0.18 \\
\multirow{3}{*}{150} & \multirow{2}{*}{1000} & 1500 & 7852.6 & 1981.01 & 99.05 & \\
& & & 9755.3 & 1987.60 & 99.38 & \\
& & & 9765.9 & 2484.7 & 99.39 & 0.17 \\
\hline
\end{tabular}

\section{Robustness:}

TABLE 8: ROBUSTNESS STUDY

\begin{tabular}{|c|c|c|c|c|}
\hline S. no. & Parameters & Variation & Concentration (ng/band) & $\%$ RSD \\
\hline \multirow[t]{3}{*}{1} & Time from application to & $(0,30,60,90 \mathrm{~min})$ & 1000 & 0.48 \\
\hline & development & & 2000 & 0.76 \\
\hline & & & 3000 & 0.82 \\
\hline \multirow[t]{3}{*}{2} & Time from development to & $(0,30,60,90 \mathrm{~min})$ & 1000 & 0.42 \\
\hline & scanning & & 2000 & 0.51 \\
\hline & & & 3000 & 0.39 \\
\hline \multirow[t]{3}{*}{3} & Scanning wavelength & $267 \pm 1 \mathrm{~nm}$ & 1000 & 0.33 \\
\hline & & & 2000 & 0.43 \\
\hline & & & 3000 & 0.37 \\
\hline
\end{tabular}


Summary of Validation Study:

TABLE 9: SUMMARY OF VALIDATION PARAMETERS

\begin{tabular}{ccc}
\hline S. no. & Validation parameters & Darunavir \\
\hline 1 & Linearity Equation & $\mathrm{y}=3.7762 \mathrm{x}+371.9$ \\
$\mathrm{r}^{2}=0.992$ \\
& & $500-3000 \mathrm{ng} / \mathrm{band}$ \\
2 & Precision $(\% \mathrm{RSD})$ & \\
& Intraday & 0.25 \\
& Interday & 0.41 \\
3 & Assay \pm RSD & $99.89 \pm 0.55$ \\
4 & Accuracy \pm RSD & $\%$ Recovery \\
& 50 & $100.60 \pm 0.26$ \\
& 100 & $99.26 \pm 0.18$ \\
& 150 & $99.54 \pm 0.17$ \\
5 & Limit of Detection & $95.12 \mathrm{ng} / \mathrm{band}$ \\
6 & Limit of Quantitation & $288.24 \mathrm{ng} / \mathrm{band}$ \\
7 & Specificity & Specific \\
8 & Robustness & Robust \\
\hline
\end{tabular}

CONCLUSION: An accurate, rapid, specific and stability-indicating HPTLC method was developed for the estimation of Darunavir Ethanoate in the bulk and pharmaceutical dosage form.

In the developed method, no interferences were observed from blank or excipients at Darunavir peak retention. The primary advantage of this method is that it is simple and accurate with a shorter run time.

Hence, the proposed method can be conveniently adopted for the routine quality control analysis in bulk and formulation. The developed method was validated according to $\mathrm{ICH}$ guidelines.

ACKNOWLEDGEMENT: The authors are thankful to Cipla Ltd., Kurkumbh for providing the gift sample of Darunavir for studies.

\section{CONFLICTS OF INTEREST: Nil}

\section{REFERENCES:}

1. ICH Q2 (R1): 2005 Validation of Analytical Method, November 2012.

2. Snyder L and Kirkland J: Introduction to Modern Liquid Chromatography: John Wiley \& Sons Inc, Ed $3^{\text {rd }}, 2009$.

3. Deshpande PB: Development and validation of stabilityindicating HPTLC method for determination of darunavir ethanolate and ritonavir. International Journal of Pharmacy and Pharmaceutical Sciences 2015; 7(6): 66-71.

4. Ghante MR: Development and validation of UV spectrophotometric method for estimation of Darunavir Ethanoate in bulk and tablet dosage form. Int J Pharmacy and Pharmaceutical Sciences 2014; 6(7): 240-42.

5. Bokka R: HPTLC method for determination of darunavir in rat plasma and its application pharmacokinetic Studies. Journal of Liquid Chromatography \& Related Technologies 2014; 36(2): 167-79.

6. Kogawa AC: Validation of a stability indicating capillary electrophoresis method for the determination of Darunavir in tablets and comparison with the of infrared absorption spectroscopic method. World Journal Pharmacy and Pharmaceutical Sciences 2014; 3(6): 283-97.

7. Nageswara R: LC-MS/MS structural characterization of stress degradation products including the development of a stability indicating assay of Darunavir: an anti-HIV drug. J of Pharmaceutical and Biomedical Anal 2014; 89: 28-33.

8. Kogawa AC: Development and validation of infrared spectroscopy method for the determination of darunavir in tablets. Physical Chemistry 2013; 3(1): 1-6.

9. Vanukuri SS: Validated UV spectrophotometric methods for the estimation of Darunavir by absorption maxima, first order derivative and area under curve in bulk and its tablet dosage form. International Journal of Pharmacy and Pharmaceutical Sciences 2013; 6(1): 568-71.

10. Reddy BVR: Stability-Indicating HPLC Method for the Determination of Darunavir Ethanoate. Journal of Chromatography Sciences 2012; 6: 1-6.

11. Patel BNB: RP-HPLC method development and validation for estimation of Darunavir Ethanoate in tablet dosage form, International Journal Pharmacy and Pharmaceutical Sciences 2012; 4(3): 270-73.

12. Patel BN: A simple and sensitive HPTLC method for quantitative analysis of darunavir ethanoate tablets. Journal of Planer Chromatography 2011; 3: 292-95.

13. Rezk NL: A novel LC-ESI-MS method for the simultaneous determination of Etravirine, Darunavir and Ritonavir in human blood plasma. Talanta 2009; 79: 1372-78.

\section{How to cite this article:}

Chabukswar AR and Gadekar AS: Development and validation of stability indicating HPTLC method for estimation of darunavir. Int J Pharm Sci \& Res 2020; 11(7): 3326-32. doi: 10.13040/IJPSR.0975-8232.11(7).3326-32.

All @ 2013 are reserved by the International Journal of Pharmaceutical Sciences and Research. This Journal licensed under a Creative Commons Attribution-NonCommercial-ShareAlike 3.0 Unported License.

This article can be downloaded to Android OS based mobile. Scan QR Code using Code/Bar Scanner from your mobile. (Scanners are available on Google Playstore) 